\title{
JÁRÁSFELISMERŐ KAMERARENDSZER KIDOLGOZÁSA NI LAB-VIEW PROGRAMOZÁSI KÖRNYEZETBEN
}

\section{DEVELOPMENT OF A GAIT RECOGNITION SYSTEM IN NI LABVIEW PROGRAMMING LANGUAGE}

\author{
Salánki Dániel, ${ }^{1}$ Sarvajcz Kornél² \\ Debreceni Egyetem, Müszaki Kar Mechatronikai Tanszék, Debrecen, Magyarország \\ ${ }^{1}$ danisalanki@gmail.com \\ ${ }^{2}$ sarvajcz@eng.unideb.hu
}

\begin{abstract}
Nowadays, the biometric identifier's world is one of the most rapidly developing security technology areas. Within the biometric identification, the research team worked in the area of gait recognition. The research team developed a complex walking recognition system in NI LabVIEW environment that can detect multiple simultaneous reference points using a universal camera and capable of matching a predetermined curve to the collected samples. In the first version, real-time processing was done with a single camera, while in the second one, two high-resolution cameras work with post-processing. The program can compare and evaluate the functions that are matched to the reference curve and the current curve in a specific way, whether two walking images are identical. The self-developed gait recognition system was tested on several test subjects by the research team and according to the results, the False Acceptance Rate was zero.
\end{abstract}

Keywords: gait recognition, biometrics, camera system, identifying, analysis.

\section{Összefoglalás}

Manapság az egyik legnagyobb ütemben fejlődő biztonságtechnikai terület a biometrikus azonosítók világa. A biometrikus azonosításon belül a járásfelismerés szakterületével foglalkozott a kutatócsoport. Sikerült megvalósítani egy olyan komplex járásfelismerő rendszert NI LabVIEW fejlesztőkörnyezetben, amely képes univerzális kamera segítségével detektálni több egyidejü referenciapontot, és képes a gyüjtött mintákra előre definiált görbét illeszteni. Az első változatban egy kamerával valós idejű feldolgozás történt, míg a másodikban már két nagy felbontású kamera dolgozik utólagos feldolgozással. A program képes a referenciagörbére és az aktuális görbére illesztett függvényeket meghatározott módon összehasonlítani és kiértékelni, hogy azonos-e két járáskép vagy sem. A saját fejlesztésű járásfelismerő rendszert több személyen is tesztelte a kutatócsoport, mely tesztek közül idegen személy esetén egyszer sem mutatott egyezést a program.

Kulcsszavak: járásfelismerés, biometria, kamerarendszer, azonosítás, elemzés.

\section{Bevezető}

Napjainkban, a világ fejlődésével, egyre inkább elterjedtnek számítanak a biometrikus azonosító rendszerek. Beléptető rendszerek, de már a legfőbb középkategóriás okostelefonok is rendelkeznek biometrikus azonosítási funkcióval, sőt, már a személyi igazolványok is tartalmazhatják az adott személy ujjlenyomatát.

Számos tudományterület van, ahol a mozgáskövető és mozgásrögzítő eszközök fontos szerepet játszanak. Ilyen például az automatizálás, a robotika és a számítógépes animáció. A különböző alkalmazási területek más-más speciális követelményeket támaszthatnak, más igények lehetnek fontosak. Van, ahol elegendő egy-két független pont követése, máshol, pl. karakter animációnál, a követett pontok komplex transzformációs hierarchiát alkotnak, ahol az egyes elemek teljes merev transzformációjának előállítására van szükség [1]. 
Az emberek gyakran érezhetik úgy, hogy egy ismerős személyt már messziről felismernek a járásuk alapján. Ez a közönséges tapasztalat az ötletadója annak a gondolatnak, hogy a járásfelismerő rendszerek is alkalmazhatók a biztonságtechnikában. Egy ember járásáról könynyen lehet képet alkotni, akár publikus helyeken is, anélkül, hogy ebből bármit is észlelne. A járást azonban több tényező is befolyásolja: lábbeli, talaj, fáradtság, aktuális lelkiállapot vagy bármilyen sérülés [2].

\section{A létrehozott járásfelismerő szoftver [3]}

2017-ben a kutatócsoport létrehozott egy 640×480-as felbontású kamerával működő kezdetleges járásfelismerő rendszert szintén LabVIEW-ban [4]. A továbbiakban a továbbfejlesztett változat kerül bemutatásra.

Az újabb változat legfőbb módosítása a korábbihoz képest, hogy immár két kamera kezelésére képes a program a korábbi egy helyett, és a nagyobb gépigény miatt valós idejű feldolgozás helyett a járás felvételre kerül, majd a videófájlt megadva a programnak történik a járáselemzés. A kamerák egymás mellé lettek helyezve annak érdekében, hogy kiegészítsék egymást. További módosítás a régi változathoz képest, hogy pontfelismerés helyett alakzatfelismerés történik, amely által jobban kiszűrhetők a hamisan érzékelt pontok, valamint, hogy az együtthatók összehasonlítása helyett a függvények határozott integrál értékei kerülnek összehasonlításra.

A program új változatának felhasználói felülete az 1. ábrán látható. Összesen 4 lap között lehet váltogatni a Tab Control funkció segítségével. Az első lapon látható a két kamera által készített felvétel, amelyek egy fix tárgyhoz lettek rögzítve. A kijelzők alatt a kiválasztandó videófájl számítógépes helye található, amik között pedig egy nagyobb zöld lámpa látható, amely felvillan, ha felismerte a program a tesztalanyt. A nagyobb lámpa fölött található 8 kisebb lámpa, amelyek 8 összehasonlítás logikai értékét jelzik. A legalsó sorban a kiválasztható sablonok helyei találhatók, jelen esetben 6 darab, kameránként 3, ugyanis a tesztalanyra minden esetben 3 sablon volt helyezve: egy az alkarra, könyök alatt, egy a térdre, egy pedig a vádlira, $36 \mathrm{~cm}$-re a talajtól. Ezeket a sablonokat fogja a program keresni a videókban. Ehhez a verzióhoz már nem szükséges Stop gomb, ugyanis a program önállóan áll le a videók elemzése után.

A felhasználói felület második lapján az érzékelt sablonok koordinátái találhatók X és $\mathrm{Y}$ szerint tömbökbe rendezve. A felhasználói felület harmadik lapján a kapott járásgörbék kijelzése történik az első, illetve a második videó esetén külön-külön, valamint az alkaron lévő sablon által leírt görbe kiértékelése mindkét videóra vonatkozóan. A kiértékelés során a sablon által leírt görbére egyenletet illeszt a program, amelynek a 0 és 1920 közötti határozott integrálját számítja ki.

A felhasználói felület negyedik lapján található a többi járásgörbe kiértékelése. Bal oldalról sorrendben az első grafikon az első videó térden lévő sablonja által leírt görbére illeszt függvényt, a második grafikon az első videó vádlin lévő sablonja által leírt görbére illeszt függvényeket, ezt szemlélteti a 2. ábra is. A harmadik és a negyedik grafikon a második videó térden, illetve vádlin lévő sablonja által leírt görbékre illeszt függvényeket. Az alkarra és a térdre helyezett sablonok esetében másodfokú illesztés történik, ugyanis ezen sablonok egy kis görbülettel rendelkező pályát írnak le, így jó közelítéssel egyenesnek tekinthetők, azonban a jobb pontosság érdekében a másodfokú tag is figyelembe lett véve. A vádlira helyezett sablon azonban nem írható le egyetlen polinomiális, hatvány vagy exponenciális függvénnyel, amelyekre lehetőséget ad a program. A megfigyelések alapján, körülbelül 3 lépés fér bele

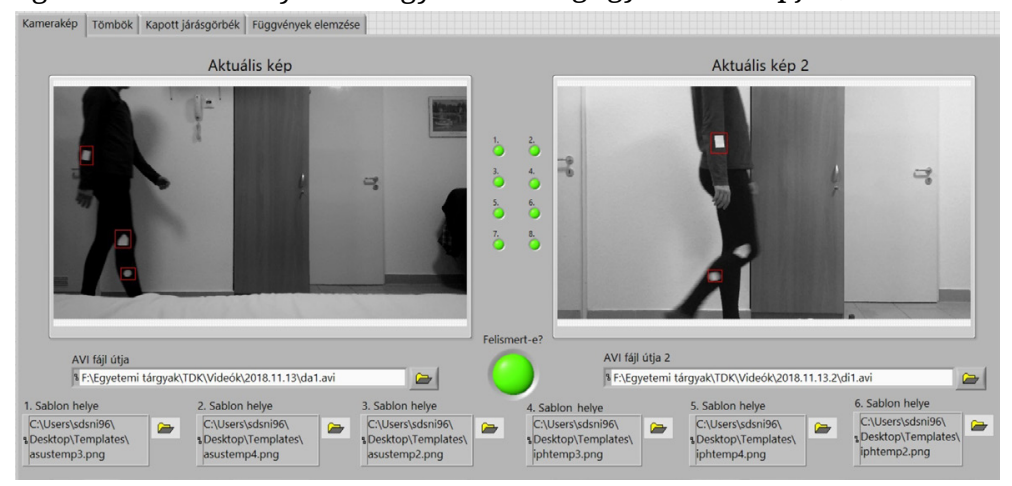

1. ábra. A járásfelismerő szoftver felhasználói felületének első lapja 
jobb lábbal a kameraképbe, amelyeket 3 másodfokú függvénnyel sikerült leírni. Az integrálási határpontokat a függvények lokális maximumai jelentik.

Több 10 mérés átlagát véve meghatározásra kerültek az egyes függvények határozott integráljainak határértékeit. Ezektől számítva, ha 5\%on belül, illetve néhány esetben, ha maximum 12,5\%-on belül esik egy adott tesztalany járásgörbéire illesztett függvényeinek határozott integrálja, akkor az a programrészlet logikai 1-et szolgáltat. Az első videó vádlira helyezett 3 járásgörbe részletére illesztett függvény határozott integrál értékeinek az összege lett képezve, ugyanis az egyes értékek között egy kisebb szórás volt megfigyelhető, viszont az összegük körülbelül állandó volt a mérések során. Ezáltal összesen 8 darab összehasonlítást végez a program, ha mindegyik logikai 1-gyel zárul, akkor a zöld lámpa felvillan, és felismertnek tekinti a tesztalanyt.

\section{Eredmények [3]}

A kamerarendszert létrehozása után több alanyon tesztelte a kutatócsoport. A mérések normál ruházatban történtek (hosszú nadrág és felső). A tesztalanyok az első lépést bal lábbal tették meg. A 3. ábra egy, a program által ismert tesztalany járásából származó eredményeket szemlélteti. Az első szürke oszlop az első 3 kék oszlop értékeinek összegét mutatja. A kék oszlopok az első kamerával készült videóból származó eredményeket mutatják. Az értékek a sablonok által leírt görbékre illesztett függvények határozott integráljait jelentik, sorrendben a vádlira helyezett sab-

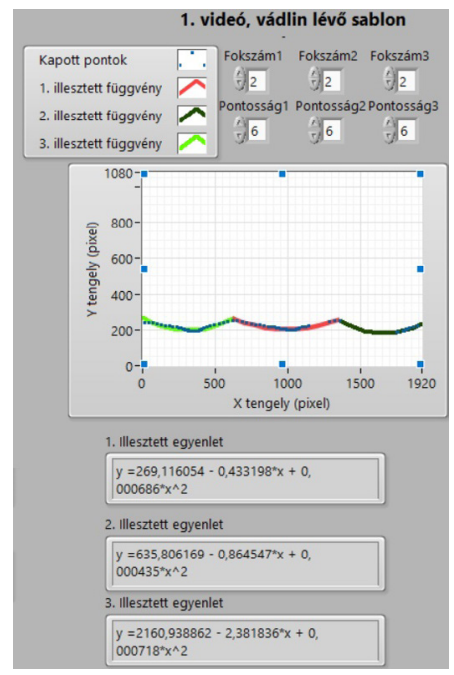

2. ábra. A negyedik lap egy részlete lon első, második és harmadik függvénye, a térd függvénye, valamint az alkarra illesztett sablon görbéjének függvénye. A zöld oszlopok a második kamera által készített videóból kapott adatokat mutatják az elsőhöz hasonló felosztásban. Az utolsó oszlop a felhasználói felületen felvillanó kis lámpák számát mutatja.

A program az általa ismert tesztalanyt 15-ből 14-szer helyesen észlelte (3. ábra). Ezáltal a téves elutasítási arány (FRR - False Rejection Rate) ebben az esetben 6,25\%-ra adódott (helyes felismerési arány: 93,75\%).

$\mathrm{Az}$ ismert tesztalanyhoz hasonló alkatú, de a program számára ismeretlen tesztalany esetében a program egyszer sem biztosított jogosultságot, tehát a téves elfogadási arány (FAR - False Acceptance Rate) 0\%-ra adódott.

\section{4. Összehasonlítás más rendszerekkel}

Dacheng Tao, Xuelong Li, Xindong Wu, és Stephen J. Maybank Gabor-szűrő alapú járás-felismerő rendszert teszteltek. A Gabor-szűrők, Dennis Gabor után elnevezve, textúra elemzésre használható lineáris szűrők [5]. A Gabor-szűrők adott irányú lineáris struktúrák felerősítésére használhatók. Ezen módszerrel 92\%-os felismerési arányt értek el különböző nézetekből és lábbelikben, aktatáskával a tesztalanyoknál pedig $87 \%$ volt a felismerési arány [6].

Khalid Bashir, Tao Xiang és Shaogang Gong által vizsgált GEI alapú (Gait Energy Image - Járás energiakép) rendszert több adatbázis alapján futtatta végig a kutatócsoport a tesztalanyok kooperálása nélküli eseteket vizsgálva. A CASIASetA adatbázis

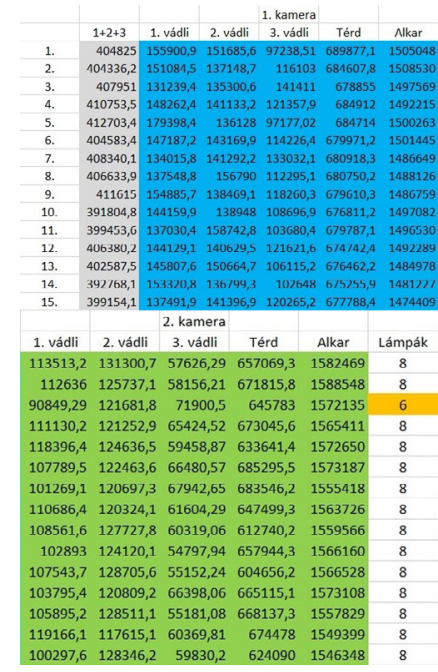

3. ábra. Ismert tesztalany járásából származó adatok 
alapján, ahol a tesztalanyoknál nincs csomag, és nem viselnek nagykabátot, a felismerési arány $100 \%$-os volt, azonban a CASIASetB és CASIASetC esetében, ahol a tesztalanyoknál csomag van, illetve nagykabátot hordanak, a felismerési arány 77,8\%, valamint 43,1\%-ra adódott [7].

Chin Poo Lee, Alan W.C. Tan és Shing Chiang Tan tranziens bináris minták (TBP - Transient Binary Patterns) használatával fejlesztettek járásfelismerő rendszert, és hasonlították össze más módszerekkel. A TBP és GEI módszerek 99\%-os felismerési arányt eredményeztek, a Prokrusztész alakvizsgálat (PSA - Procrustes Shape Analysis) 87\%, a Fourier-leírás alapú módszer 92\%, az aktív energiakép (AEI - Active Energy Image) módszer 79\%, míg a három ortogonál síkból vett lokális bináris minta alapú módszer (LBP-TOP - Local Binary Patterns from Three Orthogonal Planes) csupán 49\%-os felismerési arányt eredményeztek [8].

Gálai Bence és Benedek Csaba a járás alapú személyazonosítást és cselekvésfelismerést vizsgálták LiDAR szenzorokkal (Light Detection and Ranging - Lézer alapú távérzékelés). Egyszerre több embert ismertettek fel rendszerükkel, amely 5 személyig még 100\%-os felismerési aránnyal működik, majd fokozatosan csökken 75\%-ra 22 személy esetében, amely után stagnál [9].

A 4. ábrán összegzésre került a kutatócsoport aktuális és korábbi rendszerének, valamint más rendszerek pontossága. Ez alapján kijelenthető, hogy a legpontosabbnak a LiDAR (100\%), a TBP (99\%) és a GEI (99\%) alapú járásfelismerő rendszerek bizonyultak az eredmények alapján. A kutatócsoport által létrehozott rendszer szintén jónak számít a maga 93,75\%-os felismerési arányával, míg a legkevésbé hatékonynak az LBPTOP rendszer bizonyult 49\%-kal.

\section{5. Összefoglalás, következtetések}

Összegzésként megállapítható, hogy a kutatócsoportnak sikerült létrehoznia egy olyan komp-

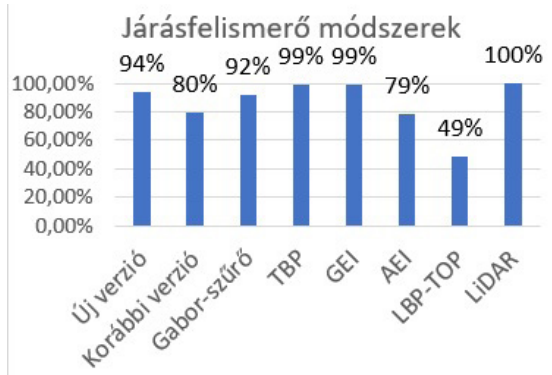

4. ábra. A kutatócsoport járásfelismerő rendszere összehasonlítva másokéval lex járásfelismerő programot NI LabVIEW fejlesztőkörnyezetben, amely képes több kamera segítségével detektálni több egyidejű sablonként elmentett mintát, és képes a gyüjtött mintákra előre definiált görbét illeszteni. A program továbbá képes a referenciagörbe és az aktuális görbe értékeit meghatározott módon összehasonlítani és kiértékelni, hogy azonos-e a két járás képe vagy sem. A saját fejlesztésű járásfelismerő rendszert több személyen is tesztelve lett, mely tesztek közül idegen személy esetén egyszer sem mutatott egyezést a program.

A továbbiakban a járásminta feldolgozási sebességén lehetne javítani olyan kamerával vagy szoftverrel, amely segítségével azonnal AVI formátumban menthető el a videó. A kutatás során használt 2014es LabVIEW verzió csak AVI videók utólagos feldolgozására képes, így a program más szoftverben való megírása (pl. OpenCV), amely képes az MP4 fájlok kezelésére, vagy amelyben a jó minőségű valós idejü kamerázás nem fogja vissza a teljesítményt, szintén javíthat a feldolgozási sebességen.

\section{Köszönetnyilvánítás}

A cikk elkészítését az EFOP-3.6.1-16-2016-00022 számú projekt támogatta. A projekt az Európai Unió támogatásával, az Európai Szociális Alap társfinanszírozásával valósul meg.

\section{Szakirodalmi hivatkozások}

[1] Viktor D.: Optikai alapú Motion Capture rendszer. 2011. 5, 7-9.

[2] Boyd J. E., Little J. J.: Biometric Gait Recognition. Springer - Verlag Berlin Heidelberg 2005, 19-42.

[3] Salánki D., Sarvajcz K., Husi G.: Járásfelismerés fejlesztése NI LabVIEW környezetben. Debreceni Egyetem Műszaki Kar, Mechatronikai mérnök BSc, szakdolgozat, 2018.

[4] Salánki D: Járásfelismerés fejlesztése NI LabVIEW környezetben. Debreceni Egyetem Müszaki Kar, Kari TDK, Debrecen, 2017.

[5] Fogel I., Sagi D.: Gabor filters as texture discriminator. Biological Cybernetics, 1989, 61.

[6] Dacheng Tao, Xuelong Li, Xindong Wu, Maybank S. J.: General Tensor Discriminant Analysis and Gabor Features for Gait Recognition. IEEE transactions on pattern analysis and machine intelligence, 2007. 1-35.

[7] Khalid Bashir, Tao Xiang, Shaogang Gong: Gait recognition without subject cooperation. Pattern Recognition Letters, 2010. 2052-2060.

[8] Chin Poo Lee, Alan W.C. Tan, Shing Chiang Tan: Gait recognition with Transient Binary Patterns. J. Vis. Commun. Image R., 2015. 69-77.

[9] Gálai B., Benedek Cs.: Járás alapú személyazonosítás és cselekvésfelismerés LiDAR szenzorokkal, 2017. 